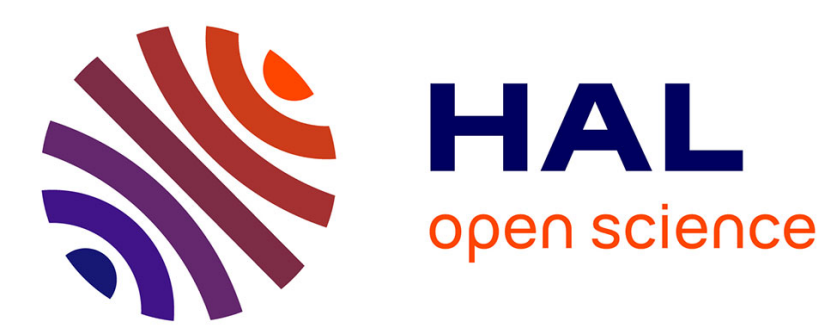

\title{
Metallocene Polypropylene Crystallization Kinetic During Cooling in Rotational Molding Thermal Condition
}

Salah Sarrabi, Séverine A.E. Boyer, Marie-France Lacrampe, P Krawczak, Abbas Tcharkhtchi

\section{To cite this version:}

Salah Sarrabi, Séverine A.E. Boyer, Marie-France Lacrampe, P Krawczak, Abbas Tcharkhtchi. Metallocene Polypropylene Crystallization Kinetic During Cooling in Rotational Molding Thermal Condition. Journal of Applied Polymer Science, 2013, 130 (1), pp.222-233. 10.1002/app.39035 . hal00984704

\section{HAL Id: hal-00984704 https://hal.science/hal-00984704}

Submitted on 30 Apr 2014

HAL is a multi-disciplinary open access archive for the deposit and dissemination of scientific research documents, whether they are published or not. The documents may come from teaching and research institutions in France or abroad, or from public or private research centers.
L'archive ouverte pluridisciplinaire HAL, est destinée au dépôt et à la diffusion de documents scientifiques de niveau recherche, publiés ou non, émanant des établissements d'enseignement et de recherche français ou étrangers, des laboratoires publics ou privés. 


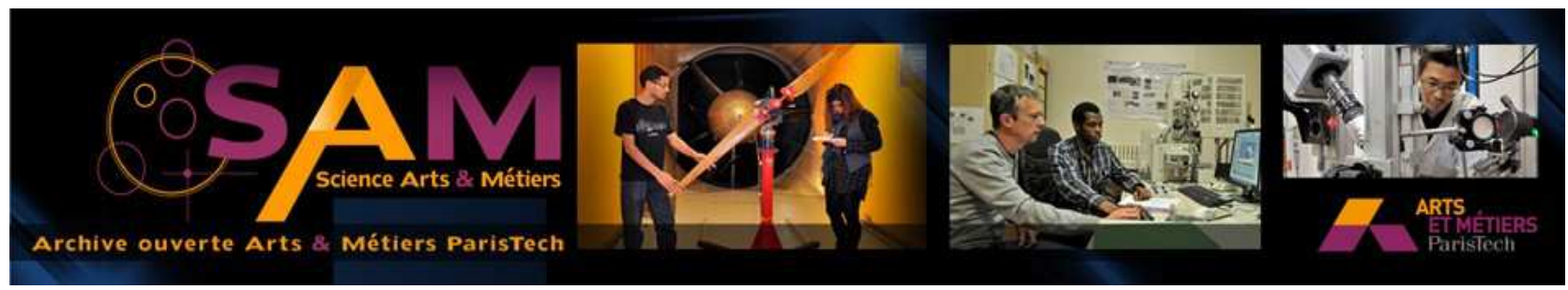

\section{Science Arts \& Métiers (SAM)}

is an open access repository that collects the work of Arts et Métiers ParisTech researchers and makes it freely available over the web where possible.

This is an author-deposited version published in: http://sam.ensam.eu Handle ID: .http://hdl.handle.net/10985/8057

\section{To cite this version :}

Salah SARRABI, S;A.E BOYER, Marie-France LACRAMPE, P KRAWCZAK, Abbas TCHARKHTCHI - Metallocene Polypropylene Crystallization Kinetic During Cooling in Rotational Molding Thermal Condition - Journal of Applied Polymer Science - Vol. 130, n¹, p.222-233 2013 


\title{
Metallocene Polypropylene Crystallization Kinetic During Cooling in Rotational Molding Thermal Condition
}

\author{
Salah Sarrabi, ${ }^{1,2}$ S. A. E. Boyer ${ }^{1}$ Marie France Lacrampe, ${ }^{1}$ P. Krawczak $^{1}{ }^{1}$ Abbas Tcharkhtchi $^{2}$ \\ ${ }^{1}$ Ecole des Mines de Douai, Departement TPCIM, 941 rue Charles Bourseul, BP 10838, F59508 Douai, France \\ ${ }^{2}$ Arts et Metiers ParisTech, PIMM, 151 boulevard de I'hôpital 75013 Paris, France \\ Correspondence to: S. Sarrabi (E-mail: salah.sarrabi@mines-douai.fr)
}

\begin{abstract}
This article is part of an ambitious project. The aim is to simulate mechanical properties of rotomolded part from microstructure consideration. Main objective here is to consider metallocene polypropylene crystallization kinetic (PP) during cooling stage in rotational molding. Crystallization kinetic of metallocene PP is so rapid that microscopy cannot help to observe nucleation and growth. Crystallization rate can be estimated by a global kinetic. Given that cooling in rotational molding is dynamic with a constant rate, Ozawa law appears more appropriate. Ozawa parameters have been estimated by differential scanning calorimetry. In rotational molding thermal condition, Avrami index identifies a complex nucleation intermediate between spontaneous and sporadic. Ozawa rate constant is 68 times higher than this obtained for Ziegler-Natta PP. By coupling transformation rate from Ozawa model and a thermal model developed earlier, the difference between theory and experimental is less than $1 \%$. To optimize rotational molding, study has been completed by sensitivity to adjustable parameters.
\end{abstract}

\section{INTRODUCTION}

Polypropylene (PP) is a semicrystalline polymer which has been extensively studied in recent decades. The wide knowledge of these properties has contributed to increase its presence in the industry of automotive, furniture, packaging, etc. This number is increasing today with new metallocene PP. These materials are obtained with a metal precursor as Titanium, Zirconium, and Hafnium. ${ }^{1-3}$ The advantages are numerous: a homogeneous microstructure distribution, ${ }^{3}$ a narrow molar mass distribution, ${ }^{4}$ a lower melting temperature $\left(140^{\circ} \mathrm{C}\right.$ against $\left.160-170^{\circ} \mathrm{C}^{5,6}\right)$, a higher crystallization temperature measured in the top of the exotherm peak obtained by differential scanning calorimetry (DSC) measurements at $10^{\circ} \mathrm{C} \min ^{-1}$ for a sample weight of 10 $\mathrm{mg}\left(120^{\circ} \mathrm{C}\right.$ against $\left.109^{\circ} \mathrm{C}^{7}\right)$, and a better thermal stability. ${ }^{8,9}$ Moreover, mechanical and optical performances of part become better for a reduced cycle time. ${ }^{10-19}$ But, the increasing of crystallization kinetic during cooling stage does not allow any microstructure observation. ${ }^{20,21}$ Metallocene materials were then stimulated great interest. ${ }^{22}$ To simulate the crystallization kinetics of metallocene polymers, global kinetics have often been used. However, few studies describe PP global kinetics during dynamic cooling.

\section{Global Kinetics of Crystallization}

From a global point of view, semicrystalline polymers crystallization is divided mainly into two stages: a nucleation followed by a growth. Once nucleation appears, crystal growth arises by successive deposits of macromolecular chains portions in crystal growth front. ${ }^{23,24}$ When crystals intrude on each other, primary crystallization process stops and annex crystallization can take place. This annex crystallization can be of two types: improvement of initially poor crystals named "crystal perfection" or "annealing" and secondary crystallization that usually refers to formation of new crystallites in noncrystallized areas, like insertion of secondary lamellae. Secondary crystallization can theoretically begin as soon as primary lamellae are created, but, because of relatively slow crystallization, the latter only happens when crystals are nearly or fully completed. ${ }^{25}$ Various kinetics theories describe evolution of crystalline entities during cooling. These theories assume that potential germs are distributed regularly in sample volume. ${ }^{26}$ The volume transformation rate, noted $a$, is defined by the ratio of volume processed $\left(V_{t}\right)$ and the total volume of convertible sample $\left(V_{t, t}\right)$ :

$$
a 1 / 4 \frac{V_{t}}{V_{t ; t}} 1 / 41-e^{-E ð t p:}
$$


$E(t)$ is the average number of semicrystalline entities reaching any point in the volume during time $(t)$. When sample is semicrystalline, $a$ reaches a value of 1 or $100 \%$ at end of crystallization. Absolute degree of crystallinity, noted $X_{c}$, is then obtained by multiplying $a$ and the maximum degree of crystallinity (X1):

$$
X_{c} 1 / 4 a * X 1
$$

Isothermal Crystallization, Avrami-Evans Theory Avrami-

Evans theory describes isothermal crystallization. ${ }^{26-29}$ In addition to assumptions common to all kinetics theories (see previous paragraph), theory of Avrami-Evans made additional assumption. Germs activation frequency $(q)$ and growth rates of semicrystalline entities $(G)$ are constants. Two extreme cases of nucleation can be distinguished:

- Instant germination which can be seen when $q$ is very high. In this case, all germs start to grow from an initial instant.

- Sporadic germination when $q$ is low. In this case, germs start to grow throughout crystallization.

In general, the rate of transformation is written:

$$
\text { a } 1 / 41-e^{-k_{A}^{*} t n}
$$

Avrami index $(n)$ depends on geometric characteristics of growth. Avrami constant $\left(k_{A}\right)$ depends on temperature, geometry, and germs concentration. These two constants also depend of germination. In the case of an instantaneous nucleation in 3D (Spherulite), $n 1 / 43$. In the case of sporadic germination in $3 \mathrm{D}, n$ $1 / 4$ 4. In practice, the values of $n$ obtained are not entire. ${ }^{25}$ Germination is usually intermediate between sporadic and instantaneous. $^{25}$

Dynamical Crystallization: Case of Constant Cooling Rate Ozawa Law. Ozawa law describes crystallization when cooling rate is constant. ${ }^{30}$ In general case, the Ozawa model is written:

$$
a 1 / 41-e^{-\substack{k_{O Z} \\ v \text { ref }}}
$$

$k_{\mathrm{oz}}$ is Ozawa constant, $n$ is Avrami index, and $V_{\text {ref }}$ is cooling rate.

In some particular case, ${ }^{31}$ Ozawa model not fit crystallization kinetics of a polymer under dynamic conditions. Several reasons may explain nonvalidity of Ozawa model: the presence of additives or fillers which accelerate crystallization kinetics or a high cooling rate. ${ }^{31}$

Mo Law. Mo et al. $^{32}$ describe crystallization kinetics of semicrystalline polymers during cooling at constant rate. Mo law is a combination of Avrami and Ozawa models:

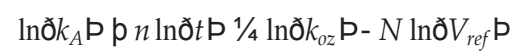

$k_{\mathrm{oz}}, N$ are Ozawa parameters and $k_{A}, n$ are the Avrami parameters. This expression is also written:

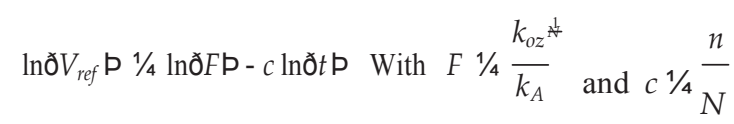

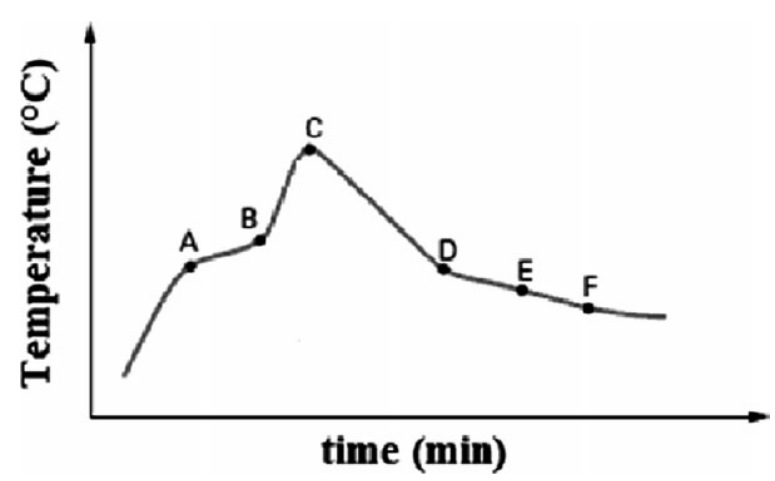

Figure 1. T-t diagram obtained during the rotational molding of a thermoplastic. ${ }^{43}$

$F$ corresponds to cooling rate at a unit crystallization time when polymer reaches a certain value of crystallinity. By plotting $\ln$ $\left(V_{\text {ref }}\right)$ versus $\ln (t)$, a line is obtained: $c$ corresponds to slope and $\ln (F)$ to intercept. Generally, Mo model was applied to PEEK, ${ }^{32}$ nanocomposites, ${ }^{33,34}$ and polymer blends. ${ }^{35-37}$ It was also used ${ }_{38,39}$ model non isothermal crystallization of polyolefins.

Crystallization Kinetics During Cooling at Any Rate:

Nakamura Theory

Generally, Nakamura theory described polymer crystallization when cooling is complex ${ }^{40,41}$ but it can be used to describe polymer crystallization during cooling at constant rate. ${ }^{42}$ This general expression is written:

$$
a 1 / 41-e^{-}{ }_{0}^{\mathrm{R}_{t}} k_{\mathrm{N}} d t^{n}
$$

$n$ is Avrami index, $k_{N}$ is Nakamura function which depend on temperature and time.

Nakamura is occasionally used in literature because it describes polymers crystallization kinetics during complex cooling generally. Most of time, cooling during polymers processing (extrusion, injection molding, rotational molding,...) is isothermal or dynamic with a constant rate.

Therefore, from a previously mentioned model, the crystallization kinetics of all semicrystalline polymers can be described during processing. The next paragraph identifies cooling rates in the particular case of rotational molding.

Rotational Molding

Rotational molding is a polymer processing technique for production of cheap and hollow parts. ${ }^{43}$ Its principle is relatively easy. Material in powder form is introduced into a mold. Then, mold is led to oven to undergo heating. After heating, polymer in a molten state is led to cooling room. When temperature is sufficiently low, part is demolded. To follow these steps, an experimental solution is to place a thermocouple sensor inside mold (in internal air) and measure temperature evolution. Associated curve is called $T-t$ diagram or temperature-time diagram. An example of $T-t$ diagram is shown (Figure 1). $T-t$ diagram is divided into seven main steps: 
- Until point A, temperature of inner wall of mold has not reached melting point of polymer. The grains, in contact with wall, remain solid.

- At point A, the inner wall of mold reaches melting point of polymer. A first layer of molten polymer is formed on this wall.

- From point A to point B, air temperature rises more slowly than initially because of gradual melting of polymer.

- At point B, all layers are melted. Internal air temperature rises to point $\mathrm{C}$. Maximum temperature (or peak of internal air temperature (PIAT)) is carefully chosen to provide sufficient fluidity to polymer to form a homogeneous system. Also, the choice of this temperature is crucial to avoid polymer degradation. ${ }^{44}$

- At point $\mathrm{C}$, heating is stopped. Mold in rotation enters in cooling room. Internal air temperature decreases up to point $\mathrm{D}$.

- At point $\mathrm{D}$, polymer begins its crystallization. Cooling rate decreases under exothermic effect of crystallization. Point E represents end of crystallization.

- At point F, internal air temperature is low and part can be demolded.

Researchers have simulated $T-t$ diagram since the beginning of 1990s. Several models were proposed. All models are derived from thermal transfer presented by Throne et al. ${ }^{45}$ Crawford et al. ${ }^{46-48}$ proposed a first model in which polymer powder passes from a solid state in a liquid state without enthalpy variation. From a theoretical point of view, this first model is physically unrealistic, because fusion is an endothermic transition. It is thus not surprising that it leads to serious mistakes, and particularly, they were unable to predict existence of a melting stage. Gogos et al. ${ }^{49,50}$ are first authors to consider melting endothermic character of polymer in model. They have proposed a model with two phases in which liquid polymer is separated from a solid polymer powder by an interface. Polymer powder passes from a solid in a liquid state during heating when interface temperature reached melting temperature. However, the numerical results presented here ${ }^{49}$ are relatively heavy and complex because of a solid/liquid interface change after each iteration. One conclusion of this work was that melting stage cannot be simulated by this method. On the basis of this report, Tcharkhtchi et al. ${ }^{51}$ used a more adapted method to describe phase change. This method makes possible to use only one equation to describe thermal phenomena in both two phases (liquid polymer and solid powder), and makes possible, thus, to free from the calculation of boundary conditions on liquid/solid interface. It named enthalpy method. ${ }^{52}$ This method was applied successfully in the case of a part with a thickness of $3 \mathrm{~mm}$ discretized in 30 elementary layers of $100 \mathrm{~lm}$. The resolution of this model remained still relatively heavy and only the melting of one powder has been observed. By varying "powder by powder" theory developed by Tcharkhtchi et al. ${ }^{51}$ to a "layer by layer" theory (i.e., 75 elementary layers of $40 \mathrm{~lm}$ ), ${ }^{53}$ numerical melting, and crystallization stages from $T-t$ diagram were observed. $^{53}$ However, this model overestimates crystallization during cooling stage. ${ }^{53}$

For an understanding of microstructure/properties/rotational molding relationships, a better representation of cooling stage

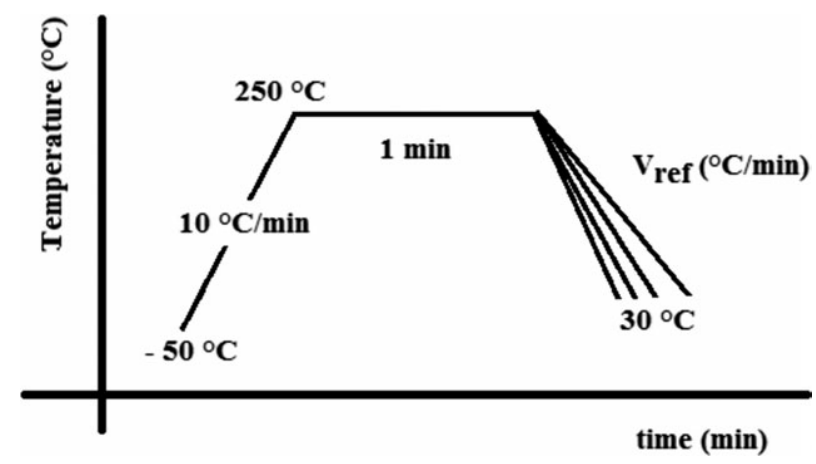

Figure 2. Schematic description of the experimental procedure used in DSC.

must be developed. To reduce gap between theory and experiment data ( $T-t$ diagram), Greco et $a l .{ }^{54}$ recommended to consider crystallization kinetics in thermal model. Cooling rate is constant in rotational molding (between 5 and $20^{\circ} \mathrm{C} \min ^{-1} 55$ or more in particular case ${ }^{56}$ ). Moreover, Ozawa model seems generally more appropriate to describe crystallization kinetic during processing. In this study, Ozawa model parameters will be characterized to deduce transformation rate of crystalline entities in the thermal conditions of rotational molding. Then, these parameters will be injected into thermal model to describe $T-t$ diagram during cooling stage.

\section{EXPERIMENTAL}

\section{Material}

The polymer under study is a rotational molding metallocene PP grade provided by ICOPOLYMERS Company. It appears as a finely micronized powder. Before processing, polymer powder was characterized by conventional laboratory techniques: DSC and size exclusion chromatography (SEC).

\section{Differential Scanning Calorimetry}

DSC tests were performed in a Q10 apparatus from TA INSTRUMENT. A sample weight of $5 \mathrm{mg}$ was used to obtain a thin film (after fusion) in the aluminum pan. Before, DSC was calibrated for temperature using indium. For Ozawa parameters measurement, different tests were performed with a constant cooling rate $\left(5,7,10\right.$, or $\left.12^{\circ} \mathrm{C} \mathrm{min}^{-1}\right)$. Figure 2 describes schematically the thermal programs used.

\section{SEC}

Analysis by SEC at high temperature, were performed on a GPCV2000 WATERS. Millennium software Version 4.00 from WATERS CORPORATION was used. The column set used was constituted with a precolumn (Styragel Guard Column $4.6 \times 30$ $\mathrm{mm}$ ) followed by three columns (Styragel HT6E Mixed bed, 10 $\mathrm{lm}, 7.8 \mathrm{~mm}$ I.D. $\times 300 \mathrm{~mm}$ ) which mass range between 500 and 7,000,000 (equivalent polystyrene (PS)). Sample was injected through a loop of $100 \mathrm{lL}$. Refractometric and viscometric detector calibrations have been carried out with standard PS. The combination of a refractometric and a viscometer detector allows a universal calibration method. It provides access to exact average molecular weights of polymers. 
Table I. Rotomolding Operating Conditions

\begin{tabular}{lllll}
\hline $\begin{array}{l}\text { Part } \\
\text { number }\end{array}$ & $\begin{array}{l}\text { Heating } \\
\text { time (min) }\end{array}$ & $\begin{array}{l}\text { Cooling } \\
\text { time (min) }\end{array}$ & $\begin{array}{l}\text { Rotational } \\
\text { speed around } \\
\text { axis 1 (rpm) }\end{array}$ & $\begin{array}{l}\text { Rotational } \\
\text { speed around } \\
\text { axis 2 (rpm) }\end{array}$ \\
\hline 1 & 25 & 20 & 9.6 & 4 \\
2 & 25 & 20 & 9.6 & 4 \\
3 & 30 & 20 & 9.6 & 4 \\
\hline
\end{tabular}

\section{Scanning Electron Microscopy (SEM)}

As explained in the introduction part, the increasing of crystallization kinetic during cooling stage does not allow any microstructure observation. ${ }^{20,21}$ To observe the microstructure of a metallocene PP grade, we have decided to decrease drastically cooling rate. For that, we have used the oven of a DSC 7 from Perkin Elmer. Before, DSC was calibrated for temperature using indium. Different cooling rates were programmed (ranging from 0.1 to $10^{\circ} \mathrm{C} \mathrm{min}^{-1}$ ). All samples (a few $\mathrm{mg}$ ) undergo the same thermal program: a heating from ambient to $250^{\circ} \mathrm{C}$ with a rate of $10^{\circ} \mathrm{C} \mathrm{min}^{-1}$ followed by a 2 -min isothermal at $250^{\circ} \mathrm{C}$ and a cooling under $\mathrm{N}_{2}\left(50 \mathrm{~mL} \mathrm{~min}^{-1}\right)$ with different cooling rates ranging from 0.1 to $10^{\circ} \mathrm{C} \mathrm{min}^{-1}$. When cycle is complete, sample and aluminum crucible were plated to gold in a SEM coating system from Polaron. SEM apparatus used here is an S$4300 \mathrm{SE} / \mathrm{N}$ from Hitachi.

\section{Processing Conditions}

To check validity of thermal kinetics model, three different spherical PP parts of thickness $2 \mathrm{~mm}$ were molded in an aluminum mold of thickness $5 \mathrm{~mm}$ and inner diameter $78 \mathrm{~mm}$, with a rotational molding machine STP LAB 40 equipped by an electrical furnace maintained at a constant temperature of $300 \mathrm{G}$

Table II. Main Characteristics of the PP Powder Under Study

\begin{tabular}{|c|c|c|}
\hline Properties & Technique (conditions) & Values in unit \\
\hline$M_{W}$ & SEC & $190 \mathrm{~kg} \mathrm{~mol}^{-1}$ \\
\hline$T_{M}$ & 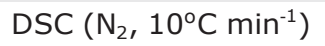 & $140^{\circ} \mathrm{C}$ \\
\hline$H_{M}$ & 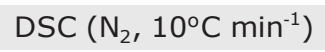 & $74 \mathrm{~kJ} \mathrm{~mol}^{-1}$ \\
\hline$T_{C}$ & $\operatorname{DSC}\left(\mathrm{N}_{2}, 10^{\circ} \mathrm{C} \mathrm{\textrm {min } ^ { - 1 } )}\right.$ & $113^{\circ} \mathrm{C}$ \\
\hline$H_{C}$ & 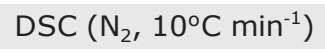 & $76 \mathrm{~kJ} \mathrm{~mol}^{-1}$ \\
\hline$x_{C}$ & $\operatorname{DSC}\left(\mathrm{N}_{2}, 10^{\circ} \mathrm{C} \mathrm{\textrm {min } ^ { - 1 } )}\right.$ & $50 \%$ \\
\hline$q_{\mathrm{sp}}$ & Technical data sheet & $854 \mathrm{~kg} \mathrm{~m}^{-3}$ \\
\hline$k_{\mathrm{sp}}$ & Literature $\left(25^{\circ} \mathrm{C}\right)^{58}$ & $0.01 \mathrm{~W} \mathrm{~m}_{1}^{-1} \mathrm{~K}_{1}^{-1}$ \\
\hline$C_{\mathrm{sp}}$ & $\begin{array}{l}\mathrm{DSC}\left(\mathrm{N}_{2}, 10^{\circ} \mathrm{C} \mathrm{min}^{-}\right) \\
\quad\left(\text { at } 25^{\circ} \mathrm{C}\right)\end{array}$ & \\
\hline$q_{\mathrm{Ip}}$ & Technical data sheet & $854 \mathrm{~kg} \mathrm{~m}^{-3}$ \\
\hline$k_{\mathrm{lp}}$ & Technical data sheet & $0.15 \mathrm{~W} \mathrm{~m}^{-1} \mathrm{~K}^{-1}$ \\
\hline$C_{\mathrm{lp}}$ & $\begin{array}{l}\text { DSC }\left(\mathrm{N}_{2}, 10^{\circ} \mathrm{C} \mathrm{min}^{-1}\right) \\
\quad\left(\text { at } 150^{\circ} \mathrm{C}\right)\end{array}$ & $1000 \mathrm{~J} \mathrm{~kg}^{-1} \mathrm{~K}^{-1}$ \\
\hline
\end{tabular}

$M_{W} 1 / 4$ weight average molar mass; $T_{M} 1 / 4$ melting temperature; $H_{M} 1 / 4$ heat of melting; $T_{C} 1 / 4$ crystallization temperature; $H_{C} 1 / 4$ heat of crystallization; $X_{C} 1 / 4$ crystallinity ratio. $q_{\mathrm{sp}} 1 / 4 / 4$ solid polymer density, $k_{\mathrm{sp}} 1 / 4$ solid polymer thermal conductivity, $C_{\mathrm{sp}} 1 / 4$ solid polymer calorimetric capacity, $q_{\mathrm{lp}} 1 / 4 \mathrm{liq}-$ uid polymer density, $k_{1 \mathrm{p}} 1 / 4$ liquid polymer thermal conductivity, $C_{1 \mathrm{p}} 1 / 4$ liquid polymer calorimetric capacity.
Table III. Main Characteristics of Mold

\begin{tabular}{lll}
\hline Properties & Source & Values in unit \\
\hline$q_{m}$ & Literature $^{59}$ & $2700 \mathrm{~kg} \mathrm{~m}^{-3}$ \\
$k_{m}$ & Literature $^{60}$ & $218 \mathrm{~W} \mathrm{~m}^{-1} \mathrm{~K}^{-1}$ \\
$C_{m}$ & Literature $^{60}$ & $950 \mathrm{~J} \mathrm{~kg}^{-1} \mathrm{~K}^{-1}$ \\
\hline
\end{tabular}

$20^{\circ} \mathrm{C}$. The corresponding operating conditions are presented in Table I. The difference is heating time. All other parameters were identical (i.e., duration of air-cooling stage, rotation rates around principal and secondary axes (numbered 1 and 2, respectively)). During processing operations, internal air temperature $T_{a}$ was measured in the center of mold with a thermocouple sensor (Rotolog system). Rotolog system consists of three basic components: a control station on PC, a base unit, and a sender unit. The control station communicates with the base unit that communicates with the sender unit on a wireless basis. Thermocouple sensors are attached to the sender unit to measure oven, polymer, or internal mold temperatures. ${ }^{57}$

\section{RESULTS AND DISCUSSION}

The various "material" parameters were identified in experiments at laboratory (when that was possible) or were compiled in the literature. Principal polymer thermal characteristics are given, respectively, on Table II. Aluminum constituted the mold. Their characteristics are reported on Table III. Lastly, the convection coefficients of external air (between furnace and mold) and internal air (located at mold center) are given on Table IV. Some thermograms obtained with Rotolog system ${ }^{57}$ are presented in Figure 3. The various heating times are indicated on curves $\left(20,25\right.$, and $30 \mathrm{~min}$ at $\left.300^{\circ} \mathrm{C}\right)$. By approximating heating and cooling stages by a straight line, it was possible to determine graphically heating and cooling rates. From this approach, it was found a value of 10 \& $1^{\circ} \mathrm{C} \mathrm{min}^{-1}$ $\left(V_{\text {ref }}\right)$ for both rates.

\section{SEM Pictures}

Figure 4 compares the sample microstructure observed on the metallocene PP surface after using the protocol describes before (see SEM in Experimental section) for different cooling rate (from 0.1 to $10^{\circ} \mathrm{C} \mathrm{min}^{-1}$ ). Morphology increases when cooling rate decreases. For both rates, crystals are considered as spherulites with an average diameter about $50 \mathrm{~lm}$ at $0.1^{\circ} \mathrm{C} \mathrm{min}{ }^{-1}$ and $10-20 \mathrm{~lm}$ at $0.5^{\circ} \mathrm{C} \mathrm{min}^{-1}$. At higher rate $\left(10^{\circ} \mathrm{C} \mathrm{min}{ }^{-1}\right.$ corre-

sponding to cooling rate in rotational molding), morphology is not clear. ${ }^{61-63}$ For the next study, crystalline entities will be assimilating to spherulites with smaller diameter (less than 50 $\mathrm{nm}$ ). This result leads to analyze crystallization rate by a global

Table IV. Main Characteristics of Air

\begin{tabular}{lll}
\hline Properties & Source & Values in unit \\
\hline$h_{\mathrm{ea}}$ & Literature $^{49}$ & $25 \mathrm{~W} \mathrm{~m}^{-2} \mathrm{~K}^{-1}$ \\
$h_{\mathrm{ia}}$ & Literature $^{49}$ & $5 \mathrm{~W} \mathrm{~m} \mathrm{~K}^{-1}$ \\
$q_{a}$ & Literature $^{50}$ & $1 \mathrm{~kg} \mathrm{~m}^{-3}$ \\
$C_{\mathrm{pa}}$ & Literature $^{50}$ & $1010 \mathrm{~J} \mathrm{~kg}^{-1} \mathrm{~K}^{-1}$ \\
\hline
\end{tabular}




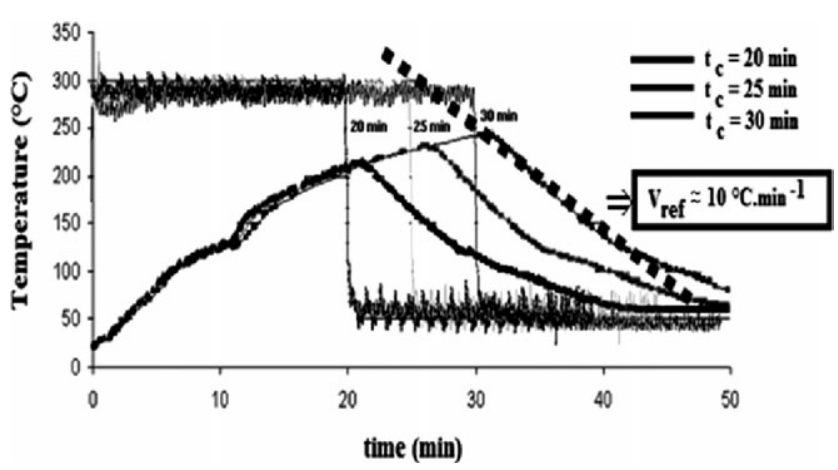

Figure 3. T- $t$ diagrams obtained for the three selected operating conditions (see Table VI). Various heating times are mentioned on curves.

kinetics. Given that cooling in rotational molding is dynamic with a constant rate (here, $10^{\circ} \mathrm{C} \mathrm{min}^{-1}$ ), Ozawa law appears more appropriate.

\section{Crystallization Kinetics Modeling (Ozawa Parameters)}

The recording of crystallization peak and rate of transformation $a$ for each cooling rate allow identifying Ozawa parameters. Figure 5 loads curves $a$ versus temperature at different cooling
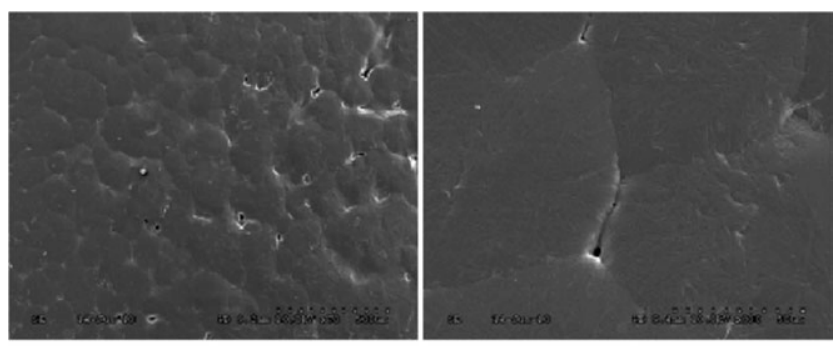

$0.1^{\circ} \mathrm{C} / \mathrm{min}$
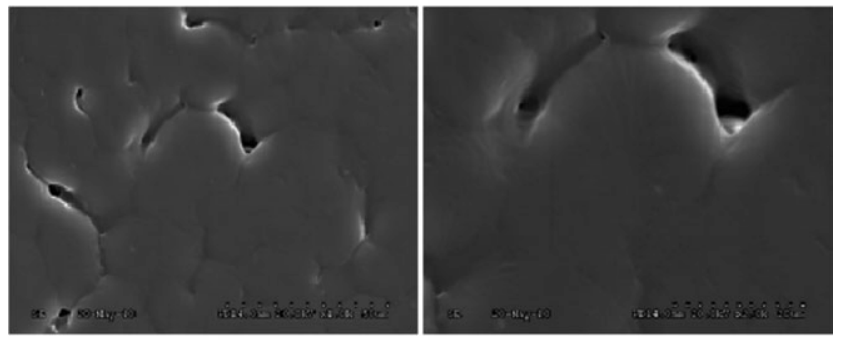

$0.5^{\circ} \mathrm{C} / \mathrm{min}$
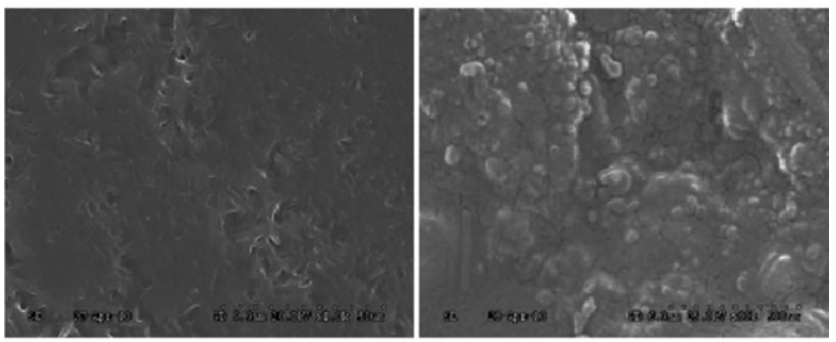

$10^{\circ} \mathrm{C} / \mathrm{min}$

Figure 4. Microstructure from metallocene PP during cooling at $0.1^{\circ} \mathrm{C}$ $\min ^{-1}$ (top), $0.5^{\circ} \mathrm{C} \min ^{-1}$ (middle), and $10^{\circ} \mathrm{C} \mathrm{min}^{-1}$ (bottom).

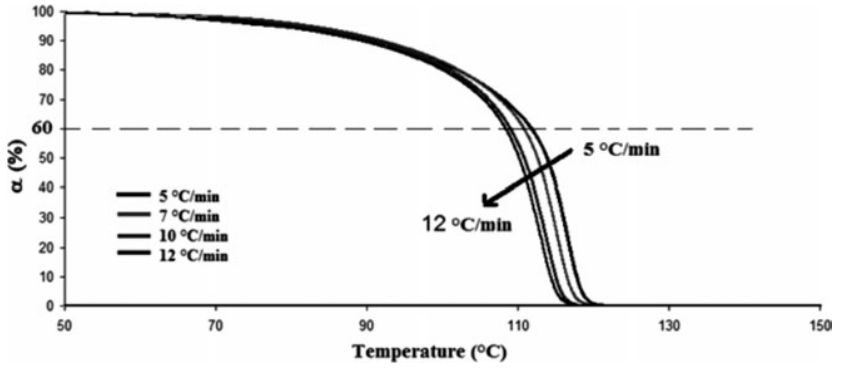

Figure 5. Rate of transformation $a$ versus temperature for different cooling rates $\left({ }^{\circ} \mathrm{C} \mathrm{min}^{-1}\right)$.

rates. Sigmoid curves, typical of a crystallization phenomenon where germination and growth coincide, ${ }^{25}$ were obtained. Those sigmoid curves shifted towards lower temperatures when cooling rate increases. Ozawa model gives evolution of $a$ as a func-

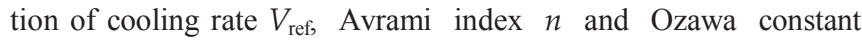
$k_{\mathrm{oz}}$. After calculation, equation of Ozawa can be written as follows.

$$
\ln 1 / 2-\ln ð 1-a \mathrm{P}] 1 / 4 \ln ð k_{O Z} \mathrm{P}-n \ln ð V_{r e f} \mathrm{P}
$$

By plotting $\ln [-\ln (1-a)]$ versus $\ln \left[V_{\text {ref }}\right]$ for each temperature (near to $T_{\mathrm{C}}$ ), a line with a slope $n$ and an intercept $\ln k_{\mathrm{oz}}$ was obtained. Figure 6 shows the curves obtained for different temperatures $\left(112.5,113.5,114.5,115,115.5,116\right.$, and $\left.117^{\circ} \mathrm{C}\right)$. Figure 6 shows two line segments with different slopes. ${ }^{64-66} \mathrm{In}$ fact, delimited part corresponds to high transformation rate ( $a$ $>60 \%$ ), which describes secondary crystallization, while second section describes primary crystallization $(a<60 \%)$. In next paragraph, only points below $60 \%$ will be considered because secondary crystallization obeys another form of growth and global models do not consider it yet. Figure 7 shows evolution of $\ln [-\ln (1-a)]$ versus $\ln \left[V_{\text {ref }}\right]$ for $a<60 \%$. By making a linear regression by straight lines, an index of 3.5 was obtained (Table V). Recall that for spherulitic growth in 3D, an Avrami index of 3 is characteristic of instant germination with activation of germs simultaneously while an index of 4 is characteristic of sporadic germination which allows activation of germs at different times. Therefore, a complex mechanism of crystallization is observed. This corresponds to an intermediate position between instantaneous and sporadic germination. During dynamic cooling of Ziegler-Natta PP, some authors ${ }^{67-70}$ obtain

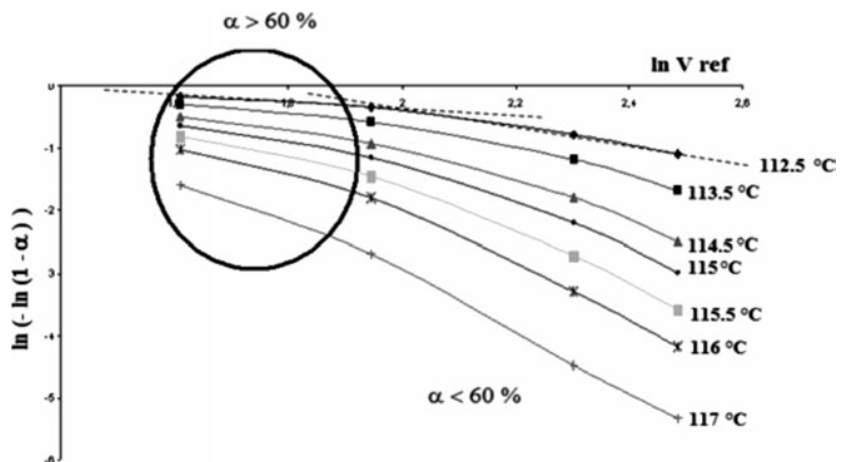

Figure $6 . \ln [-\ln (1-a)]$ versus $\ln \left[V_{\text {ref }}\right]$ for different temperatures. 


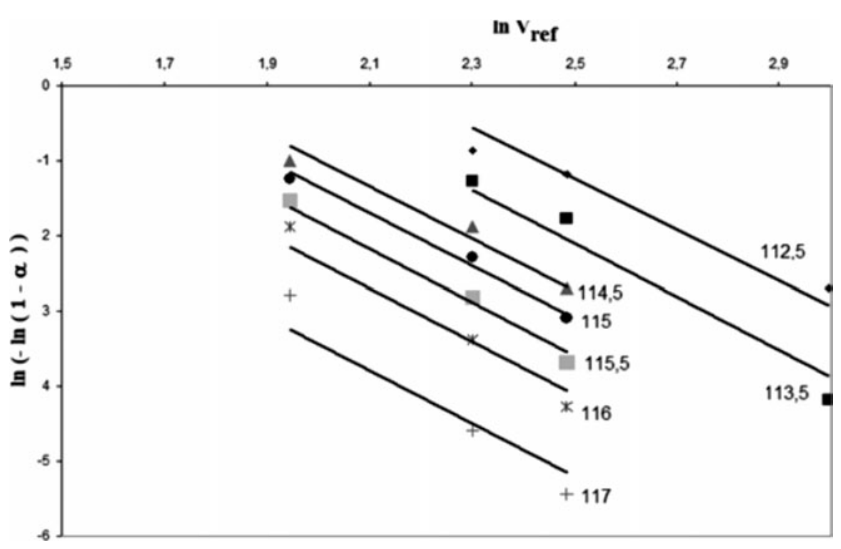

Figure 7. $\ln [-\ln (1-a)]$ versus $\ln \left[V_{\text {ref }}\right]$ for different temperatures.

an index between 1.7 and 2.8. Metallocene PP has an index higher than value from Ziegler-Natta PP. Dobreva et al. ${ }^{70}$ obtained a similar index, between 3.4 and 3.9, during the dynamic cooling of metallocene PP. In dynamic condition, crystallization of metallocene PP seems to be governed by a nucleation intermediate between sporadic and instantaneous whereas crystallization of Ziegler-Natta PP seems to be governed by an instantaneous nucleation with activation of all germs simultaneously. The value of 3.5 obtained here will be conserved for simulation. Finally, values of $k_{\mathrm{oz}}$ for each temperature are determined at the intercept of these lines. Figure 8 shows evolution of $k_{\mathrm{oz}}$ with temperature. After calculation, Ozawa constant can be written:

$$
k_{o z} 1 / 4 e^{-0: 82 T p 99: 3}
$$

After calculation, Dobreva et al. ${ }^{70}$ obtained a comparable expression $k_{o z} 1 / 4 e^{-0.75 T p 89.3}$ (Figure 8). However, these results differ with Ziegler-Natta. At $117^{\circ} \mathrm{C}$, for example, Ozawa constant is four times higher than that obtained by Garnier et al. ${ }^{71}$ with a Ziegler-Natta PP. At $116^{\circ} \mathrm{C}$, Ozawa constant is 12 times higher for metallocene PP. At lower temperature, the gap increases until obtain a ratio of 68 at $113.5^{\circ} \mathrm{C}$. In other words, crystallization kinetics of metallocene PP is faster.

Nevertheless, crystallization kinetics of metallocene is more sensitive to temperature variations. For example, in a dynamic cooling, a variation of $1^{\circ} \mathrm{C} \min ^{-1}$ leads to a difference in transformation rate (in crystalline entities) of $4.5 \%$ at $113^{\circ} \mathrm{C}$ and $10 \%$ at $110^{\circ} \mathrm{C}$. With a cooling rate of $11^{\circ} \mathrm{C} \mathrm{min}^{-1}$, entity

Table V. Avrami Index “ $n$ ” Versus Temperature

\begin{tabular}{lll}
\hline $\mathrm{T}\left({ }^{\circ} \mathrm{C}\right)$ & $\mathrm{n}$ & $\mathrm{R}^{2}$ \\
\hline 112.5 & 3.4 & 0.92 \\
113.5 & 3.5 & 0.96 \\
114.5 & 3.5 & 0.95 \\
115 & 3.5 & 0.98 \\
115.5 & 3.5 & 0.98 \\
116 & 3.5 & 0.95 \\
117 & 3.5 & 0.92 \\
\hline
\end{tabular}

Table VI. Effect of Mold Thickness on Cooling Rate of Polymer Layer "7" Located at $40 \mathrm{~lm}$ from Inner Mold Wall and Polymer Layer "47" Located at $1.6 \mathrm{~mm}$ from Inner Mold Wall

\begin{tabular}{cll}
\hline $\begin{array}{l}\text { Mold thickness } \\
(\mathrm{mm})\end{array}$ & $\begin{array}{l}\text { Cooling rate }\left(R^{2}\right) \\
\text { Layer «7 } ~\end{array}$ & $\begin{array}{l}\text { Cooling rate }\left(R^{2}\right) \\
\text { Layer « } 47 \text { » }\end{array}$ \\
\hline 5 & $11(0.994)$ & $10.9(0.99)$ \\
8 & $9.6(0.995)$ & $9.49(0.99)$ \\
10 & $8.4(0.996)$ & $8.35(0.99)$ \\
\hline
\end{tabular}

crystalline transformation is maximal at $106.9^{\circ} \mathrm{C}$ against $107.4^{\circ} \mathrm{C}$ at $10^{\circ} \mathrm{C} \mathrm{min}^{-1}$. If you want to precisely describe the microstructure of these materials during dynamic cooling, the precise knowledge of temperature is essential. Our previous works $^{53}$ show a difference of $10 \%$ between experimental and numerical $T-t$ diagram (during cooling stage). At rv 45 min from rotational molding operation, experimental temperature of internal air is $101^{\circ} \mathrm{C}$ while numerical temperature is $110^{\circ} \mathrm{C} .{ }^{53}$ This leads to a total transformation of entity crystalline at $101^{\circ} \mathrm{C}$ against $87.7 \%$ at $110^{\circ} \mathrm{C}$. To optimize rotational molding cycle time and predict mechanical properties with care, $T-t$ diagram should be considered with better precision.

\section{T-t Diagram Modeling}

All thermal equations and significance of each term, necessary for thermal modeling, are described in previous works. ${ }^{53,72}$ This thermal model was computed and solved numerically in a commercial software package (Matlab), to predict local temperature changes against processing time, in any place of polymer part and in internal air. The model was rewritten in finite differences using a centered implicit scheme for space and a decentered implicit scheme for time. It was then integrated using an implicit Euler algorithm of first order. Enthalpy method was selected to describe melting and crystallization polymer phase changes. Rate of transformation $a$ has been added to enthalpy during cooling to consider crystallization kinetics.

\section{Experimental Validation of Thermal Cycle Modeling}

Figure 9 describes cooling stage of different polymer layers. Cooling rate is almost constant (between 10.9 and $11^{\circ} \mathrm{C} \min ^{-1}$ ) and justifies employing Ozawa model. Simulations of $T-t$ diagram are reported on Figure 10. A good agreement is observed between theory and experimental data. During melting phase,

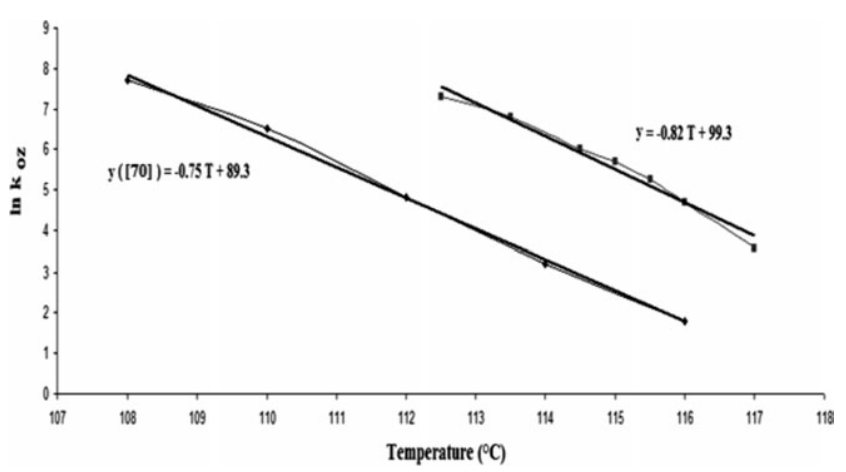

Figure 8. Ozawa constant versus temperature: comparison with Ozawa constant value from literature [70]. 


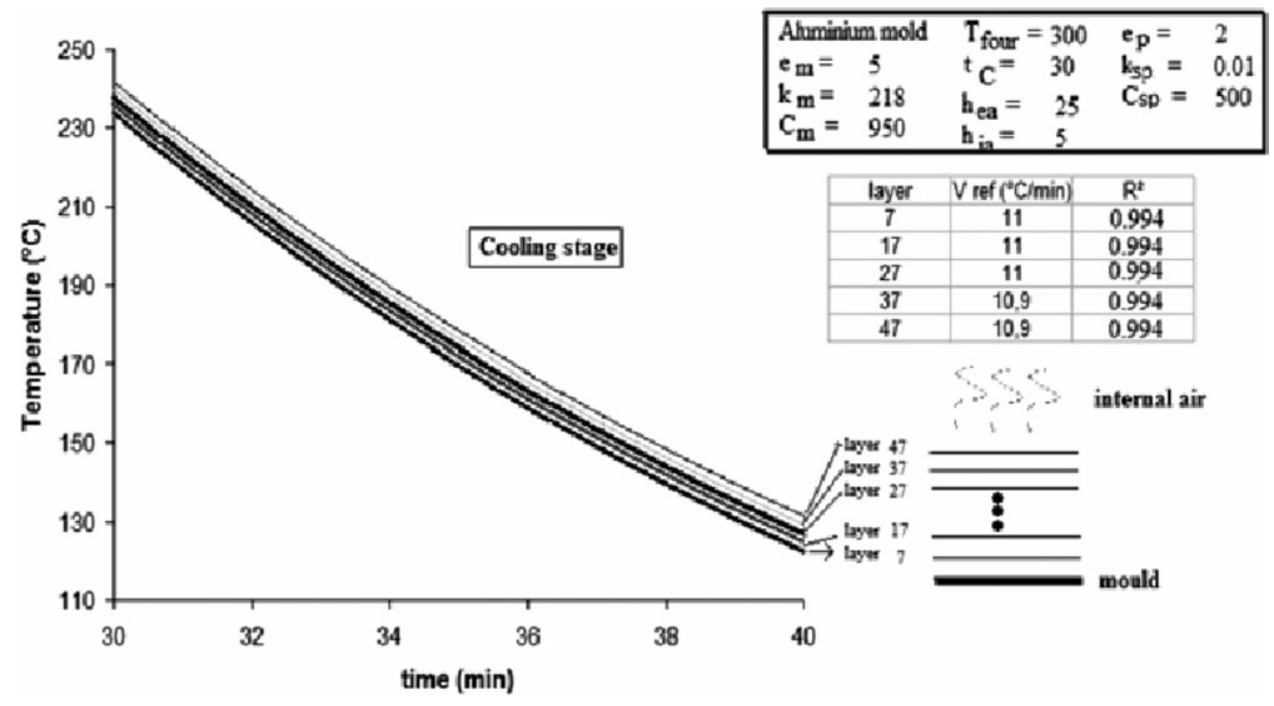

Figure 9. Numerical evolution of temperature from different polymer layers during cooling. Layers 7 (situated at $40 \mathrm{~lm}$ from mold) and 47 (situated at $1.6 \mathrm{~mm}$ from mold).

the use of enthalpy method with "layer by layer'" theory does not degrade results obtain previously by Tcharkhtchi et al. with "powder by powder" theory. ${ }^{51}$ However, during cooling stage, considering kinetics of crystallization allows a better prediction of internal air evolution. The maximum error of $10 \%$ obtained previously ${ }^{53}$ is corrected by introduction of Ozawa model. So, Ozawa is applicable to precisely describe crystallization kinetics of metallocene PP during cooling in rotational molding with a gap between theory and experiment data less than $1 \%$ ( $T-t$ diagram). To evaluate the final microstructure of parts, the evolution of polymer temperatures profiles is important. Figure 11 compares two polymer layers temperature evolutions for one selected operating conditions $\left(T_{\text {four }} 1 / 4300^{\circ} \mathrm{C}, t_{C} 1 / 430 \mathrm{~min}\right)$. Layer 7 is situated at $40 \mathrm{~lm}$ from mold and Layer 47 is situated at $1.6 \mathrm{~mm}$ from mold. We can note the difference of temperature between those two layers (1 and 2 for Layer 47; 3 and 4 for Layer 7).

\section{Sensitivity to Adjustable Model Parameters}

In this paragraph, influence of various adjustable parameters on $T-t$ diagram and temperature of some polymer layers have been tested. Recall that precise knowledge of internal air temperature has an effect on material microstructure and therefore on the mechanical performance of part.

\section{Influence of Transfer Thermal Coefficient}

The thermal coefficient of transfer $h_{\text {ea }}$ between oven and external layer of mold is an adjustable parameter. It is a constant which it is necessary to fix. Literature shows different values:

- Olson et al. [48] take a value of $24 \mathrm{~W} \mathrm{~m}^{-2} \mathrm{C}^{-1}$ with an aluminum mold (with a $6.6 \mathrm{~mm}$ thickness).

- Gogos et al. [49] get a value of $19.3 \mathrm{~W} \mathrm{~m}^{-2} \mathrm{C}^{-1}$ with an aluminum mold (with a $2.1 \mathrm{~mm}$ thickness).

- Tcharkhtchi et al. [51] choose a value of $20 \mathrm{~W} \mathrm{~m}^{-2} \mathrm{C}^{-1}$ with an aluminum mold (with a $5 \mathrm{~mm}$ thickness).

Figure 12 presents numerical $T-t$ diagram obtained with three coefficients $\left(20,25\right.$, and $\left.30 \mathrm{~W} \mathrm{~m}^{-2} \mathrm{C}^{-1}\right)$ and for a furnace maintained at $300^{\circ} \mathrm{C}$. Thanks to experimental results, we note that a value of $25 \mathrm{~W} \mathrm{~m}^{-2} \mathrm{C}^{-1}$ presents a real sense in our case. Olson et al. ${ }^{48}$ find a similar result. Also, variation of this value leads to changes in polymer layer temperature. For example, a variation of $20 \%$ shifts PIAT to $5 \mathrm{~min}$.

Moreover, Figure 13 shows that a value of $21.5 \mathrm{~W} \mathrm{~m}^{-2} \mathrm{C}^{-1}$ leads to thermal gradient in part thickness after $50 \mathrm{~min}$ of rotational molding operation (heating during $30 \mathrm{~min}$ at $300^{\circ} \mathrm{C}$ and cooling for $20 \mathrm{~min}$ ). In a thickness part of $2 \mathrm{~mm}$, if cooling is stopped at $20 \mathrm{~min}, 820 \mathrm{~lm}$ of polymer are fully crystallized while $1180 \mathrm{~lm}(37.5 \%)$ are being crystallized. The final microstructure would be different between polymer layers. In other words, precise measurement of convection coefficient is necessary. There should be an experimental protocol to measure it inside each rotational molding machine.

Mold Thickness Influence

Many thickness of aluminum mold have been introduced. In these experiments, maximal temperature has been fixed at $300^{\circ} \mathrm{C}$. Figure 14 shows numerical $\mathrm{T}-t$ diagram obtained with a 5 , 8 , and $10 \mathrm{~mm}$ mold thickness. Naturally, internal air is heated fast when mold thickness is small. After $5 \mathrm{~min}$, internal air temperature reaches $89^{\circ} \mathrm{C}$ for a mold of $5 \mathrm{~mm}$ thickness against 77 and $70^{\circ} \mathrm{C}$ for a mold of 8 and $10 \mathrm{~mm}$ thickness, respectively. Also, melting stage is shifted in time when mold thickness increases. At peak temperature (PIAT), plus mold thickness is larger and more PIAT decreases. PIAT, respectively, reached a temperature of 250,236 , and $225^{\circ} \mathrm{C}$ for a mold of 5 , 8 , and $10 \mathrm{~mm}$ thickness. In addition, a thin mold reduces cooling time and parts can be demolded earlier. Thus, the optimization of cycle time depends also on mold thickness. The more its thickness decreases and the more internal air is cooling rapidly. It reached $100^{\circ} \mathrm{C}$ after 15 min of cooling with a mold of $5 \mathrm{~mm}$ thickness against $92^{\circ} \mathrm{C}$ with a mold of $10 \mathrm{~mm}$ thickness for the same time of cooling. At a cooling rate of $11^{\circ} \mathrm{C} \mathrm{min}^{-1}$, we have seen before that the rate of transformation on crystalline entities is maximal at $106.9^{\circ} \mathrm{C}$. In Figure 14, this temperature is reached 

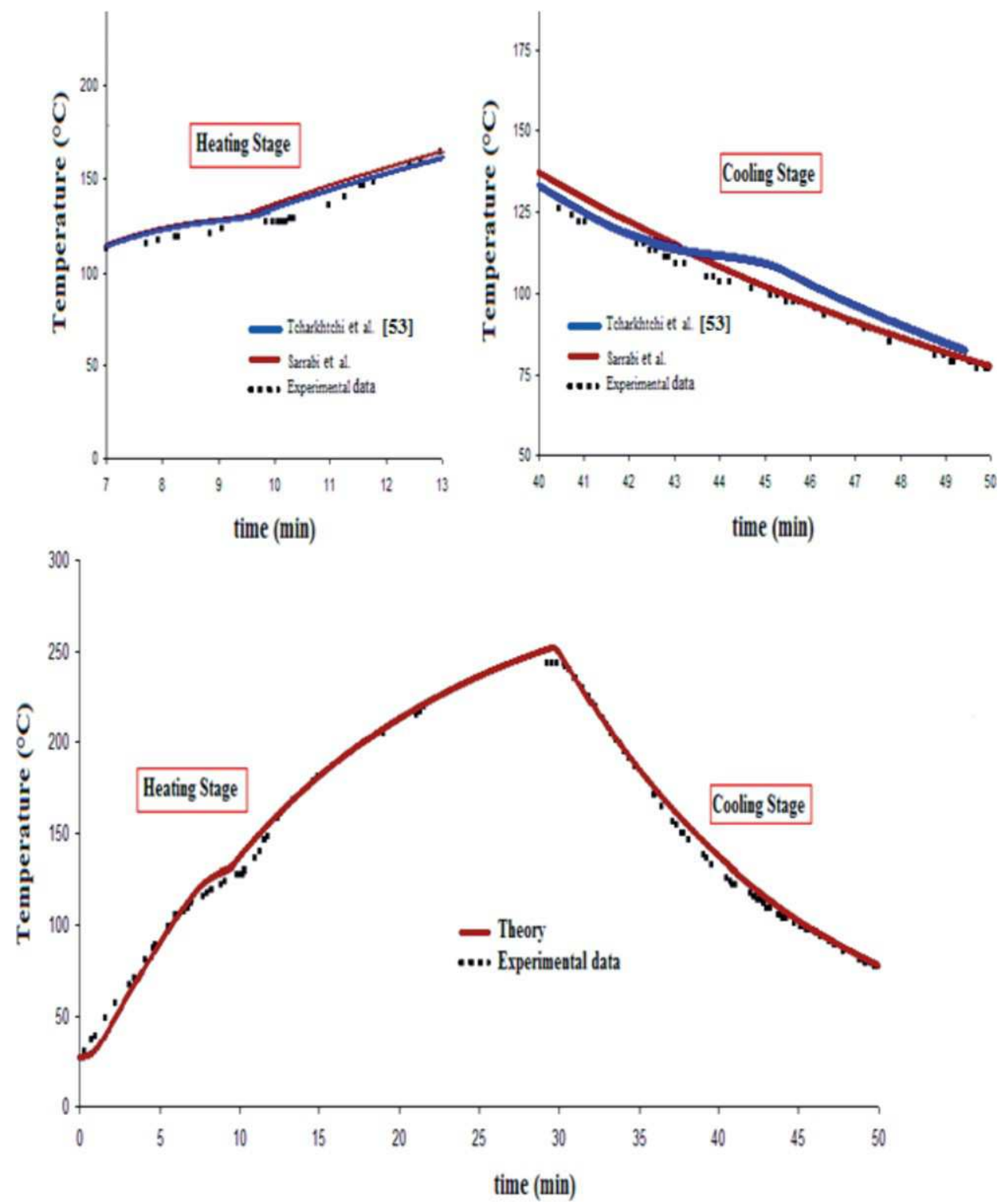

Figure 10. Internal air temperature evolutions for one selected operating conditions. Comparison between experimental and numerical results $\left(T_{\text {four }} 1 / 4\right.$ $300^{\circ} \mathrm{C}, t_{C} 1 / 430 \mathrm{~min}$ ). [Color figure can be viewed in the online issue, which is available at wileyonlinelibrary.com.]

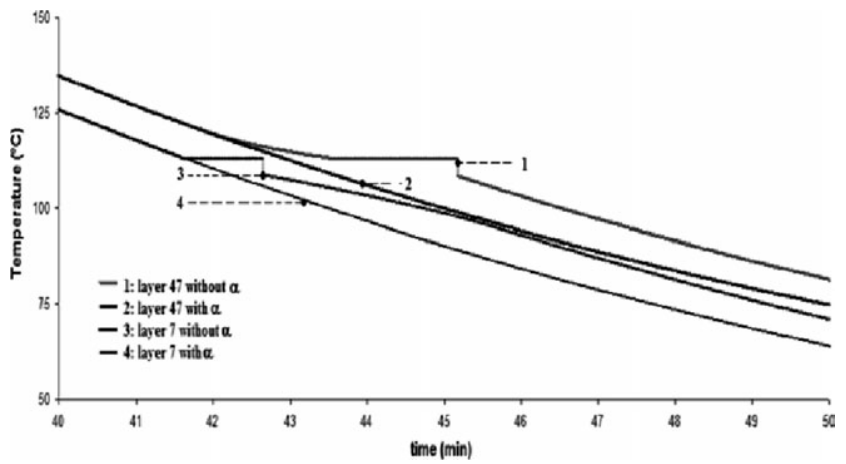

Figure 11. Some "polymer layer" temperature evolutions for one selected operating conditions $\left(T_{\text {four }} 1 / 4300^{\circ} \mathrm{C}, t_{\mathrm{C}} 1 / 430 \mathrm{~min}\right)$. Layer 7 is situated at $40 \mathrm{~lm}$ from mold and Layer 47 at $1.6 \mathrm{~mm}$ from mold.

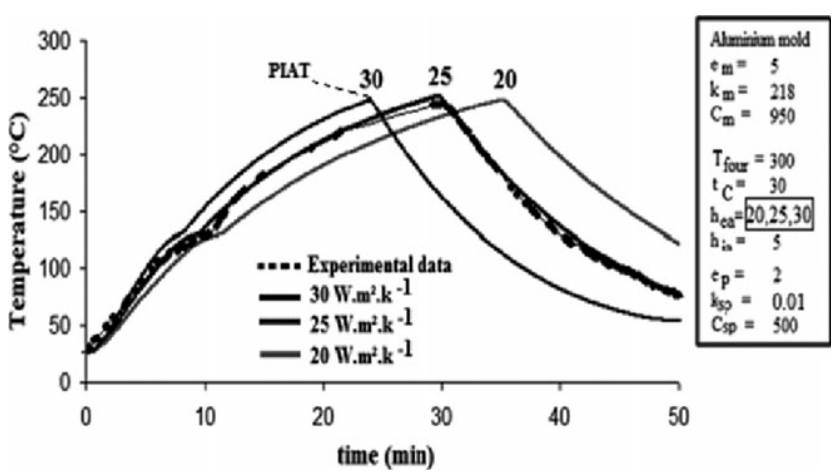

Figure 12. Numerical $T-t$ diagrams obtained with the various coefficients of thermal transfer $h_{\mathrm{ea}}$ indicated $\left(h_{\mathrm{ea}} 1 / 420,25\right.$, and $30 \mathrm{~W} \mathrm{~m}^{2} \mathrm{~K}^{-1}, T_{\text {four }} 1 / 4$ $\left.300^{\circ} \mathrm{C}\right)$. 

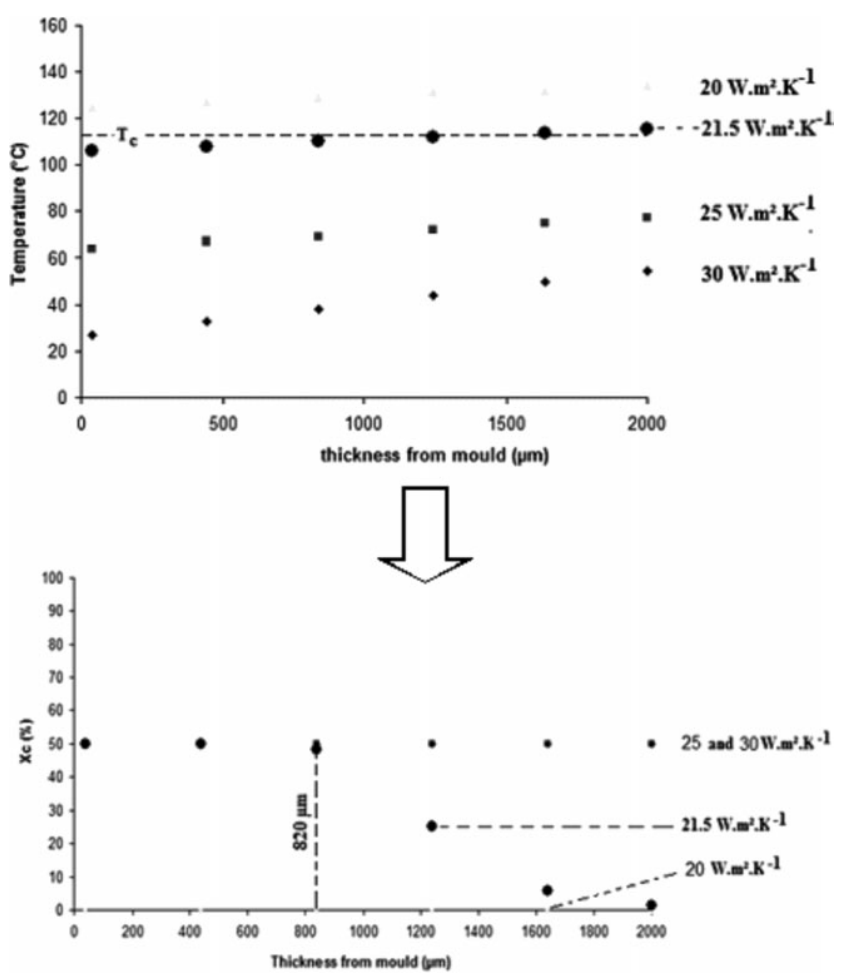

Figure 13. Influence of convection coefficient on temperature (top) and crystallinity ratio (down) of different polymer layers during cooling. $h_{\text {ea }} 1 / 4$ $20,21.5,25$, and $30 \mathrm{~W} \mathrm{~m}^{2} \mathrm{~K}^{-1}, T_{\text {four }} 1 / 4300^{\circ} \mathrm{C}, t_{\mathrm{C}} 1 / 430 \mathrm{~min}$, cooling time $1 / 420 \mathrm{~min}$ ).

for a cycle time of $43.8,45.4$, and $46.2 \mathrm{~min}$ for a mold of 5,8 , and $10 \mathrm{~mm}$ thickness. To improve time cycle in rotational molding, a mold of $5 \mathrm{~mm}$ thickness can reduce the cycle time of $2 \mathrm{~min}$ at least.

Figure 15 shows some numerical polymer layers temperature evolution obtained with a 5, 8, and $10 \mathrm{~mm}$ mold thickness. Table VI describes influence of mold thickness on cooling rate of polymer layers number 7 located at $40 \mathrm{~lm}$ from inner mold wall and polymer layers number 47 located at $1.6 \mathrm{~mm}$ from inner mold wall. More mold thickness increases and more cooling rate decreases. If material crystallizes completely at $106.9^{\circ} \mathrm{C}$, it means that Layer 7 is fully crystallized at $42 \mathrm{~min}$ for a mold

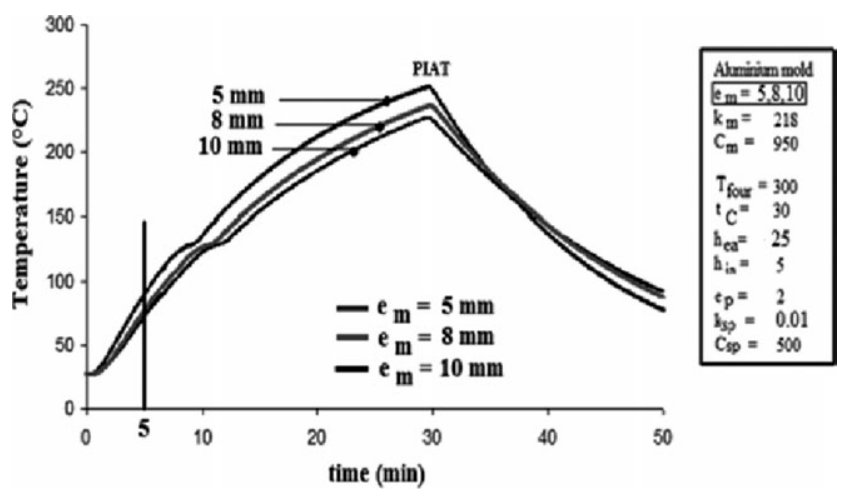

Figure 14. Mold thickness influence $(5,8$, and $10 \mathrm{~mm})$ on $T-t$ diagram $\left(T_{\text {four }} 1 / 4300^{\circ} \mathrm{C}, t_{C} 1 / 430 \mathrm{~min}\right)$.

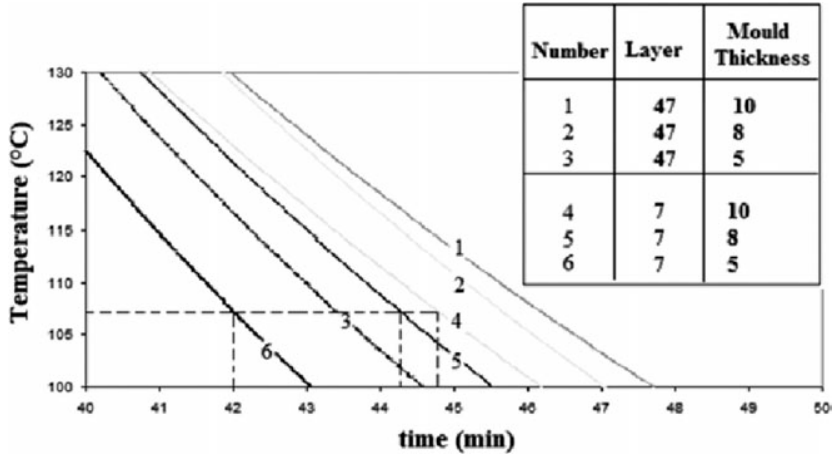

Figure 15. Mold thickness influence $(5,8$, and $10 \mathrm{~mm})$ on polymer layer temperature $\left(T_{\text {four }} 1 / 4300^{\circ} \mathrm{C}, t_{C} 1 / 430 \mathrm{~min}\right)$.

of $5 \mathrm{~mm}$ thickness while it crystallized completely at 44.1 and $44.7 \mathrm{~min}$ for a mold of 8 and $10 \mathrm{~mm}$ thickness.

\section{CONCLUSIONS}

The first part of an ambitious project aim to simulate the microstructure of semicrystalline polymers in rotational molding is realized.

A thermal model considering crystallization kinetic during cooling in rotational molding was developed in the particular case of metallocene PP.

Moreover, the crystallization kinetics of metallocene polymer is so rapid that morphology of crystals cannot be distinguished. A more detailed analysis with lower cooling rates has allowed visualizing the microstructure of metallocene PP considered as spherulites with 1 an average diameter of 50 and $10-20 \mathrm{~lm}$ at 0.1 and $0.5^{\circ} \mathrm{C} \mathrm{min}^{-}$

Therefore, Ozawa model has been used to represent the metallocene PP crystallization kinetics during cooling in rotational molding. The various parameters of model were derived from thermograms obtained by DSC. Avrami index identifies a complex nucleation intermediate between spontaneous and sporadic. Ozawa rate constant is 68 times higher than that obtained from conventional Ziegler-Natta PP at $113.5^{\circ} \mathrm{C}$ (crystallization temperature of metallocene PP). In other words, crystallization of metallocene PP is faster.

By coupling Ozawa model with a thermal model previously developed, the error of $10 \%$ between numerical and experimental $T-t$ diagram (during cooling stage) decreased considerably.

The study has been completed by model adjustable parameters analysis. A variation of convection coefficient of $20 \%$ shifts the PIAT to $5 \mathrm{~min}$. Also, this variation leads to change in each polymer layer temperature. However, cooling rate is identical between each metallocene PP layer studied. The final microstructure would be similar.

A last part describes an optimization of the process by decreasing mold thickness (simulation). In fact, to improve time cycle in rotational molding, a mold thickness of $5 \mathrm{~mm}$ reduces cycle time of $2 \mathrm{~min}$ in comparison with a mold thickness of 8 or $10 \mathrm{~mm}$. 
Next step will consist to couple this model with a $3 \mathrm{D}$ code to predict the microstructure of metallocene PP part or others polymers after the rotational molding operation.

\section{NOMENCLATURE}

$T_{\text {four }}$
$t_{C}$
$k_{m}$
$h_{\text {ea }}$
$q_{m}$
$C_{m}$
$k_{p}$

$q_{p}$

$a_{L}$

$C_{p}$

$h_{\text {ia }}$

$\mathrm{Ma}$

Cpa

$A_{\mathrm{pa}}$

$q_{a}$

$T_{M}$

$T_{C}$

$q_{\mathrm{sp}}$

$H_{0}$

$L^{0}$

$H_{M}$

$H_{C}$

$a$

$k_{\mathrm{oz}}$

$V_{\text {ref }}$

$N$

L

$R$

$d_{m}$ oven temperature

heating stage whole duration

mold thermal conductivity

external air convection coefficient

mold density

mold calorimetric capacity

polymer thermal conductivity (in the case of solid polymer $\left(k_{\mathrm{p}}=\mathrm{k}_{\mathrm{SP}}\right)$ or liquid polymer $\left(k_{\mathrm{p}}=\mathrm{k}_{\mathrm{IP}}\right)$

polymer density (in the case of solid polymer $\left(q_{P}=q_{S P}\right)$ or liquid polymer $\left(q_{P}=q_{l P}\right)$

dilatation coefficient of amorphous phase at $25^{\circ} \mathrm{C}$

polymer calorimetric capacity (in the case of solid polymer $\left(C_{P}=C_{\mathrm{sp}}\right)$ or liquid polymer $\left(C_{P}=C_{\mathrm{IP}}\right)$

internal air convection coefficient

internal air mass

air calorimetric capacity

internal air surface

internal air density

melting temperature

crystallization temperature

solid polymer density, $C_{\mathrm{sp}}$ solid polymer calorimetric capacity

reference heat value at the reference temperature $\left(T_{1}^{1 / 4} T_{0} \quad 1 / 4298 \mathrm{~K}\right)$

melting latent heat

melting enthalpy

crystallization enthalpy

mass transformation rate

Ozawa constant

cooling rate

Avrami constant

distance between mold center and oven

mold radius

mold diameter

\section{REFERENCES}

1. Archie, E.; Hamielec, Joao, Soares, B. P. Prog. Polym. Sci. 1996, 21, 651.

2. Benedikt, G. M.; Goodall, B. L. Plastics Design Library; William Andrew Publishing: New York, 1998.

3. Bubeck, R. A. Mater. Sci. Eng. 1996, 39, 1.

4. Mirabella, F. M. J. Polym. Sci. Part B: Polym. Phys. 2001, 39, 2800.

5. De Rosa, C.; Auriemma, F.; Spera, C. Macromol. Symp. 2004, 218, 113.

6. Cobzaru, C.; Hild, S.; Boger, A.; Troll, C.; Rieger, B. Coord. Chem. Rev. 2006, 250, 189.

7. Macauley, N. J.; Harkin-Jones, E. M. A.; Murphy, W. R. Polym. Eng. Sci. 1998, 38, 516.

8. Shibryaeva, L. S.; Rishina, L. A.; Shatalova, O. V.; Krivandin, A. V. Polym. Sci. 2011, 53, 618.

9. Monakhova, T. V.; Nedorezova, P. M.; Tsvetkova, V. I.; Shlyapnikov, Yu. A. Polym. Sci. Ser. B 2004, 46, 744.

10. Billon, N.; Haudin, J. M.; Gadzinowska, K. J. Appl. Polym. Sci. 2005, 97, 2319.

11. Xu, L.; Xu, K.; Chen, D.; Zheng, Q.; Liu, F.; Chen, M. J. Therm. Anal. Calorim. 2009, 96, 733.

12. Archer, E. J. Cell. Plast. 2007, 43, 491.

13. Wang, X.; Harkin-Jones, E. H.; Crawford, R. J.; Fatnes, A. M. Plast. Rubber Compos. 2000, 29, 340.

14. Zhang, Y. F.; Li, E. X.; Xian-Shan, W. J. J. Therm. Anal. Calorim. 2009, 100, 661.

15. Borysiak, S., J. Therm. Anal. Calorim. 2007, 88, 455.

16. Broda, J. J. Appl. Polym. Sci. 2003, 90, 3957.

17. Charoenphol, P.; Supaphol, P. J. Appl. Polym. Sci. 2005, 95, 245.

18. Li, C.; Isshiki, N.; Saito, H.; Ogata, K.; Toyota, A. J. Polym. Sci. Part B: Polym. Phys. 2009, 47, 130.

19. Durmus, A.; Yalçınyuva, T. J. Polym. Res. 2009, 16, 489.

20. Libster, D.; Aserin, A.; Garti, N. Polym. Adv. Technol. 2007, $18,685$.

21. Boyer, S. A. E.; Silva, L.; Gicquell, M.; Devisme, S.; Chenot, J. L.; Haudin, J. M. Int. J. Mater. Form. 2008, Suppl. 1, 599.

22. Xu, J. T.; Guan, F. X.; Yasin, T.; Fan, Z. Q. J. Appl. Polym. Sci. 2003, 90, 3215.

23. Monasse, B. Ann. Chim. Fr. 1990, 15, 173.

24. Hoffman, J. D.; Miller, R. C. Polymer 1997, 38, 3151.

25. Nicodeau, C. Modelisation du soudage en continu de composites a matrice thermoplastique. PhD Thesis, ENSAM, Paris, France, September 2005.

26. Avrami, M. J. Chem. Phys. 1939, 7, 1103.

27. Avrami, M. J. Chem. Phys. 1940, 8, 212.

28. Avrami, M. J. Chem. Phys. 1941, 9, 177.

29. Evans, U. R. Transfer Faraday Soc. 1945, 41, 365.

30. Ozawa, T. Polymer 1971, 12, 150.

31. Sajkiewicz, P.; Carpaneto, L, Wasiak, A. Polymer 2001, 42, 5365.

32. Liu, T.; Mo, Z.; Wang, S.; Zhang, H. Polym. Eng. Sci. 1997, 37, 568.

33. Yuan, Q.; Awate, S.; Misra, R. D. K. Eur. Polym. J. 2006, 42, 1994.

34. Joshi, M.; Butola, B. S. Polymer 2004, 45, 4953.

35. Xiong, H.; Gao, Y.; Li, H. M. Express Polym. Lett. 2007, 1, 416.

36. Tao, Y.; Mai, K. Eur. Polym. J. 2007, 43, 3538.

37. Gao, J. G.; Yu, M. S.; Li, Z. T. Eur. Polym. J. 2004, 44, 1533.

38. Qin, J.; Li, Z. J. Appl. Polym. Sci. 2010, 115, 1256.

39. Qin, J.; Gao, J.; Li, Z.; Run, M. J. Appl. Polym. Sci. 2008, 107,1235 . 
40. Nakamura, K.; Watanabe, K.; Katayama, K.; Amano, T. J. Appl. Polym. Sci. 1972, 16, 1077.

41. Nakamura, K.; Watanabe, K.; Katayama, K.; Amano, T. J. Appl. Polym. Sci. 1973, 17, 1031.

42. Blasquez, J. S.; Borrego, J. M.; Conde, C. F.; Conde, A.; Lozano-Perez, S. J. Alloys Compd. 2012, 544, 73.

43. Crawford, R. J. In: Rotational Moulding of Plastic; Crawford, R. J., Ed.; Research Studies Press LTD: New York, 1996; Vol.2, Chapter 1.

44. Sarrabi, S.; Colin, X.; Tcharkhtchi, T. J. Appl. Polym. Sci. 2010, 118, 980.

45. Throne, J. L. Polym. Eng. Sci. 1976, 16, 257.

46. Sun, D. W.; Crawford, R. J. Plast. Rubber Compos. Process. Appl. 1993, 19, 47.

47. Nugent, P. Theoretical and Experimental Studies of Heat Transfer During Rotational Molding. PhD Thesis, The Queen's University of Belfast, Belfast, UK, 1990.

48. Olson, L. G.; Crawford, R. J.; Kearns, M.; Geiger, N. Polym. Eng. Sci. 2000, 40, 1758.

49. Gogos, G.; Olson, L. G.; Liu, X.; Pasham, V. R. Polym. Eng. Sci. 1998, 38, 1387

50. Gogos, G.; Olson, L. G.; Liu, X. Polym. Eng. Sci. 1999, 39, 617.

51. Tcharkhtchi, A.; P'erot, E.; Chinesta, F. Int. Polym. Process. 2004, 19, 296.

52. Zhou, Y.; Fernandez-Pello, A. C. Combust. Theor. Model. 2000, 4, 477.

53. Sarrabi, S. Vers une approche mecanistique du vieillissement thermique du polypropylène au cours du rotomoulage. PhD Thesis, ENSAM, Paris, France, March 2009.

54. Greco, A.; Maffezzoli, A. Adv. Polym. Technol. 2003, 22, 271.

55. Abdullah, M.; Bickerton, S.; Bhattacharyya, D.; Crawford, R. J.; Harkin-Jones, E. Polym. Eng. Sci. 2009, 49, 1846.

56. Tan, S. B.; Hornsby, P. R.; McAfee, M. B.; Kearns, M. P.; Mccourt, M. P. Polym. Eng. Sci. 2011,DOI: 10.1002.

57. Crawford, R. J.; Nugent, P. J. Plast. Rubber Compos. Process. Appl. 1992, 17, 28.

58. Laurent, M.; Vuillermoz, P. L. In Techniques de l'Ingenieur: Paris, 1993.

59. Bouralis, J.; Maeder, G. Precis de metallurgie; AFNOR: Paris-La Defense, 1997.

60. Facy, G.; Pompidou, M. Precis de fonderie: methodologie, production et normalisation, 2nd ed.; AFNOR: Paris-La Defense, 1992.

61. Churdpunt, Y.; Isayev, A. I. In Metallocene Technology in Commercial Applications; Benedikt, G. M., Ed.; Plastics Design Library: New York, 1999, 247.

62. Bond, E. B.; Spruiell, J. E. In Metallocene-Catalyzed Polymers: Materials, Properties, Processing and Markets; Benedikt, G. M.; Goodall, B. L., Eds.; Plastics Design Library: New York, 1998, 157.

63. Kukaleva, N.; Cser, F.; Jollands, M.; Kosior, E. J. Appl. Polym. Sci. 2001, 80, 831.

64. Eder, M.; Wlochowicz, A. Polymer 1983, 24, 1593.
65. Addonizio, M. L.; Martuscelli, E.; Silvestre, C. Polymer 1987, 28, 183.

66. Franbourg, A.; Rietsch, F. Ann. Chim. Fr. 1990, 15, 367.

67. Chen, G. T.; Zhang, Y.; Wan, C.; Zhang, Y. J. Appl. Polym. Sci. 2006, 100, 1889.

68. Leelapornpisit, W.; Ton-That, M. T.; Perrin-Sarazin, F.; Cole, K. C.; Denault, J.; Simard, B. J. Polym. Sci. Part B: Polym. Phys. 2005, 43, 2445.

69. Nandi, S.; Ghosh, A. K. J. Polym. Res. 2007, 14, 387.

70. Dobreva, T.; Lopez-Majada, J. M.; Perena, J. M.; Perez, E.; Benavente, R. J. Appl. Polym. Sci. 2008, 109, 1338.

71. Garnier, L.; Duquesne, S.; Bourbigot, S.; Delobel, R. Thermochim. Acta 2009, 481, 32.

72. Sarrabi, S.; Colin, X.; Tcharkhtchi, A. Materiaux Tech 2008, 96, 253.

\section{APPENDIX}

In the case of a spherical mold, a rotational molding machine can be schematized as indicated:

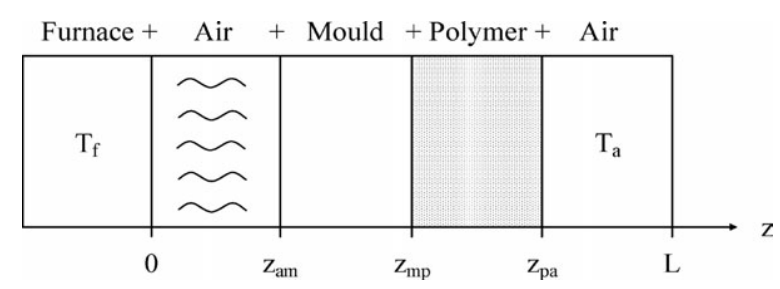

The part thickness is given by

$$
e_{\mathrm{P}} 1 / 4 z_{\mathrm{pa}}-z_{\mathrm{mp}}
$$

The thickness and inner diameter of mold are respectively given by

$$
e_{m} 1 / 4 z_{m p}-z_{a m} \text { and } d_{m} 1 / 42 L-z_{m p}:
$$

Thermal transfers take place across the different elements (furnace, external and internal air, mold, polymer part) constituting rotational molding machine, but also at the interfaces between these elements:

$$
\begin{aligned}
& \text { Tðz } 1 / 40 ; t \text { P } 1 / 4 T_{\text {four }} \quad \text { when } 01 / 4 t 1 / 4 t_{C} \\
& \text { Tðz } 1 / 40 \text {; tP } 1 / 425 \mathrm{C} \quad \text { when } t>t_{C} \\
& \left.-\mathrm{k}_{\mathrm{m}} \frac{@ \mathrm{~T}}{@ \mathrm{z}_{\mathrm{am}} ; \mathrm{t}} 1 / 4 \mathrm{~h}_{\mathrm{ea}} \frac{1}{2} \mathrm{~T} \mathrm{Tz}_{\mathrm{am}} ; \mathrm{tp}-\mathrm{T} 0 ; \mathrm{tP}\right] \\
& \mathrm{k}_{\mathrm{m}} \frac{@^{2} \mathrm{~T}}{@ \mathrm{z}^{2}} 1 / 4 q_{\mathrm{m}} \mathrm{C}_{\mathrm{m}} \frac{@ \mathrm{~T}}{@ \mathrm{t}} \\
& \text { @T @T }
\end{aligned}
$$

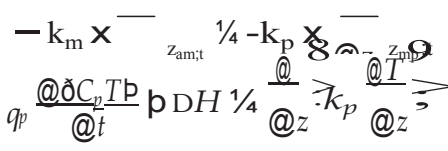




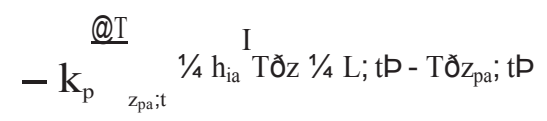

$$
\begin{aligned}
& h_{i a} 1 / 2 T \partial z 1 / 4 L-D x ; t \text { P }-T \partial z 1 / 4 L ; t \text { P] } 1 / 4 \frac{m_{a} C_{p a}}{A_{p a} \mathrm{D} t} d T \\
& A_{p a} 1 / 44 p R^{2} \\
& m_{a} 1 / 4 V_{a} q_{a}{ }_{d_{m}}{ }_{3}^{-} p R q_{a} \\
& R_{1 / 4} 2 \\
& q_{p} 1 / 4 \frac{q_{s p}}{1 \mathrm{p} a_{L} \circlearrowright T-298 \mathrm{p}}
\end{aligned}
$$

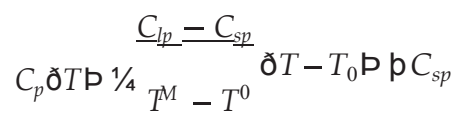

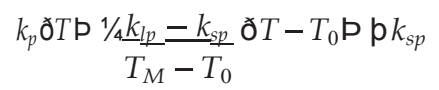

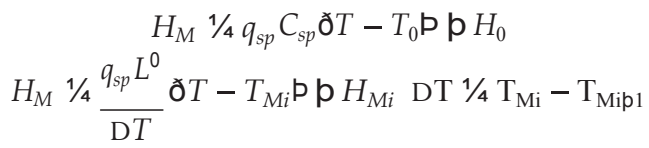

$$
\begin{aligned}
& H_{M} 1 / 4 q_{l p} C_{l p} \text { ðT - } T_{M i p 1} \text { P p } H_{M i p 1} \\
& \mathrm{DH} \quad 1 / 4-{ }^{a}{ }_{C} \\
& a 1 / 41-e^{-\substack{k_{O Z} \\
V_{r e f}^{n}}}
\end{aligned}
$$

